\title{
Regional Benefits of Logistic Clusters: A Study of Scale Development
}

\author{
DOI: 10.26466/opus.873593
}

\author{
Zümrüt Hatice SSekkeli * ${ }^{*}$ İsmail Bakan ** \\ * Asisst. Prof. Dr., Kahramanmaraş Sütçü İmam University, Kahramanmaraş/Türkiye \\ E-Mail: zhkiper@yahoo.com \\ ORCID: $0000-0001-5090-4372$ \\ **Prof. Dr., Kahramanmaraş Sütçü İmam University, Kahramanmaraş/Türkiye \\ E-Mail: ibakan63@hotmail.com \\ ORCID: $\underline{0000-0001-8644-8778}$
}

\begin{abstract}
Businesses in the same industry and companies that provide support to these industries, tend to cluster geographically in order to gain various advantages. These formations, which are named the "cluster", create value by producing goods and services, and represent the entire value chain at interrelated industry groups, from suppliers to end products, including support services. As a driving force for regional development, clusters provide industrial, sectoral, social, and environmental benefits to their regions by their common geographical location, purpose-built infrastructures, collaborations, and common goals. There are many studies in the literature emphasizing the critical importance of regional clustering at both micro and macro levels. However, no systematic study on scale development has been found. This article is aimed to develop a scale for the Benefits of Logistics Clusters and to fill this gap in the literature.In the study, 259 companies, that are members of Kahramanmaras Chamber of Commerce and engaged in foreign trade activities in different sectors, were determined and data were obtained from these companies by questionnaires. The sample size is calculated as 155 and156 questionnaires were collected. The sample size is calculated as 155 and156 questionnaires were collected. To develop the Benefits of Logistic Clustering (BLC) scale firstly the data were tested with exploratory factor analysis in SPSS; Then to validate the four factors are obtained, confirmatory factor analysis was performed with AMOS. Finally, the reliability and validity of the scale were analyzed, and found that the BLC scale was reliable and valid.
\end{abstract}

Key Words: Clustering, Logistics Clusters, Benefits of Logistic Clustering, Scale Development. 


\section{Lojistik Kümelerin Bölgesel Faydaları: Ölçek Geliştirme Çalışması}

\section{Öz}

Endüstrilerde aynı sektörde yer alan işletmeler ve bu sektörlere değer katan firmalar, çeşitli avantajlar elde edebilmek amacıyla coğrafi olarak bir araya gelerek kümelenme eğilimi göstermektedirler. Küme adı verilen bu oluşumlar, bir bölgede, mal ve hizmet üretmek yoluyla değer yaratan birbiriyle ilişkili endüstri gruplarıdır ve destek hizmetleri de dahil olmak üzere tedarikçilerden son ürünlere kadar geniş bir şekilde tanımlanmış bir endüstrinin tüm değer zincirini temsil etmektedirler. Bölgesel kalkınmada itici güç olan kümelenmeler, ortak coğrafi konumları, amaca yönelik oluşturdukları altyapıları, kurdukları işbirlikleri ve ortak hedefler sayesinde bölgelerine endüstriyel, sektörel, sosyal ve çevresel faydalar sağlamaktadır. Literatürde bölgesel kümelenmenin hem mikro hem de makro düzeyde kritik önemini vurgulayan pek çok çalışma bulunmasına rağmen, ölçek geliştirmeye yönelik sistematik bir çalışmaya rastlanmamıştır. Bu makale ile Lojistik Kümelerinin Bölgesel Faydaları için bir ölçüm ölçeği geliştirmek ve literatürdeki bu eksikliği gidermek amaçlamaktadır. Çalışmada, Kahramanmaraş Ticaret Odasına üye olan ve farklı sektörlerde dış ticaret faaliyeti gösteren 259 firma belirlenmiş ve veriler bu işletmelerden anket yoluyla elde edilmiştir. Örneklem büyüklüğ̈̈ 155 olarak hesaplanmış ve 156 adet anket toplanmıştır. Veriler sırasıyla önce SPSS 'de açıklayıcı faktör analizi ile test edilmiş, ardından elde edilen dört faktör üzerinde AMOS ile doğrulayıcı faktör analizi yapılmıştır. Çıkan sonuçlara göre Lojistik Kümelemenin Yararları (BLC) ölçeği oluşturulmuştur. Daha sonra ise ölçeğin güvenilirliği ve geçerliliği analiz edilmiş ve sonuçlara göre BLC ölçeğinin güvenilir ve geçerli olduğu bulgularına ulaşılmıştır.

Anahtar Kelimeler: Kümelenme, Lojistik Kümelenme, Lojistik Kümenin Faydalar, Ölçek Geliştirme. 


\section{Introduction}

As a result of globalization and technological developments, new economic understanding, and differentiation of competition, businesses must fight to compete more effectively. For this reason, they have sought to improve existing processes in order to gain competitive advantage in national and/or international markets (Bakan and Şekkeli, 2017, p.15). After all this search, the clustering approach was brought to the agenda by Porter in 1990 as a solution to all these problems (Delgado, Porter, and Stern, 2016, p.2). After a while, this approach became a very popular role in creating competitive advantage in today's economy (Chung, 2016, p.259).

The cluster concept is very important for the development of commercial or non-commercial enterprises in the region. The main characteristic of clusters is to cooperate with many companies to achieve the goals. Clusters allow businesses and regions to gain competitive advantage by providing measurable benefits (Dmuchowski, 2019, p.353).

Clusters are defined as geographical concentrations of industries that are interconnected to knowledge, skills, input, demand, etc., and included providing faster accession and communication to global markets, to gain a competitive advantage. Therefore, many governments have recently encouraged the development and expansion of clusters in which similar and / or related firms are geographically located to gain economic competition (Eraslan and Dönmez, 2017, p.720).

Around the world, clusters are being created not only for industrial areas but also for the service sector. Logistics clusters are one of these service industry clusters (Yıldırım and Demet, 2016, p.397). Logistics clusters have a critical role in the globalization of supply chains, such as the size, types, and aspects of flows, the ability to create individual solutions, to add value at a certain stage, etc., and provide new organizational remedies. Regional logistics activities based on a cluster concept ensure the development of logistics service capabilities for businesses operating in the cluster (Dmuchowski, 2019, p.354). For all these reasons, their number is increasing day by day around the world.

Logistics clusters bring many benefits to businesses, industries, communities and environments in that area. Measuring the levels of these benefits is extremely important. Although many studies have focused on the Benefits of 
Logistics Clusters (BLC), few studies have been able to measure these benefits. Since there is no agreed scale to measure BLC, it is difficult to evaluate and compare the findings of studies.

This study aims to fill this gap by developing a new scale. In the study, a scale of BLC was tried to be developed by using three quantitative studies Gürbüz, Ayaz, and Kebeci, 2016; Bay and Erol, 2016 and Gedik and Turgut, 2017 previously conducted. The questionnaires adapted from these three studies were applied to the people of the region. At the first step, the data was analyzed by exploratory factor analysis at SPSS. After that, the model was formed and was analyzed by confirmatory factor analysis at AMOS. The results show that the BLC scale is reliable and valid.

In the subsequent parts, the theoretical background of LC and the scale development process are reviewed and the implications of this research are discussed.

\section{Theoretical Background}

\section{Definition of Logistics Clustering}

Clustering approach is a common strategy applied worldwide, which has great importance in both national and international competitiveness policies. In clusters, there are many stakeholders (purchasing; customers; non-governmental organizations; consultancy firms; banks, etc.) who directly or indirectly cooperate with each other and collaborate on a product or service in a common geography such as a city, a region, or a country (Eraslan, Bulu, and Bakan, 2008, p.3). There have been many successful business clusters, such as Machine, Software, Home Textile, Ceramic, Organic Food, Automotive, Electric Electronics, Computing, Automotive, Processed Food, Textile, Medical, Yachting, Tourism, Logistics etc.

Logistics clustering concept, which is an application of clustering approach, was first named as logistics clusters in 2010 and logistics clusters in 2012 by Y. Sheffi, a professor at Massachusetts Institute of Technology (Ylldirım and Demet, 2016, p.397).

Logistics clusters are defined as the gathering of many logistics companies and non-logistics companies (such as supporting companies, manufacturers, wholesalers, retailers, relevant government institutions) in a special area and 
closely interacting with them to increase their operational efficiency and effectiveness. Logistics villages are located near major production centers such as industrial areas, business centers and cities (TCDD, 2017, p.96), that are making a great contribution to many issues as providing value-added services, reducing costs, providing ease of operation, achieving growth, increasing productivity, generating employment, etc. (Zaralı, Yazgan, and Delice, 2019, p.2).

Comprehensive studies have also been carried out on logistics clustering, which is one of the cluster types. In the studies Miller et al.(1996), Sun et al. (2010), Yang, et al. (2010); Elgün (2011); Kayıkçı (2010); Baki (2016), etc., had emphasized the importance of logistics cluster location selection; Lindholm and Behrends (2012) had addressed planning problems in logistics villages; Aydin and Ögüt (2008) had defined the concept of logistics village and mentioned the essential features of this logistics village; Tek and Mucan (2010) had focused on the efficiency of macro and micro-logistics villages. Tsamboulas, and Dimitropoulos (1999) and Tsamboulas and Kapros (2003) had evaluated logistics villages financially under financing uncertainty; Bezirci and Dündar (2011) had stated that logistics villages provided the advantage of costs. Olsson and Woxenius (2012) had explained the benefits of logistics centers.

After literature review, FIAS (2008), De Langen (2002) and Kasarda (2008), Rivera et.al 2016, Sheffi, 2010 examined the benefits of logistic clustering based on the positive effects of generic clusters on various dimensions. And they mentioned that the positive impacts of logistics clusters are similar to those impacts that attribute to general industrial clusters (Rivera, Gligor, and Sheffi, 2016, p.245). These benefits could be summarized as inter-firm collaboration, high levels of productivity, cost-efficiency, supply chain effectiveness, increased employment, improvement of collective learning capabilities, competitive advantage, economic development, etc. (Baydar et.al,2019).

But there was found that none of these studies measured the benefits of the logistics center using a special measurement tool. So it is aimed to fill that lack in the literature by this study. 


\section{Benefits of Logistics Clusters}

Logistics clusters provide four types of benefits to businesses from a wide range of sectors that are directly or indirectly linked to each other: economic, natural, sectoral and social (Europlatforms, 2015)

\section{Table 1. Benefits of Logistics Clusters (Aydın and Öğüt, 2008a)}

\begin{tabular}{|c|c|}
\hline Economic Benefi & ts Sub-di-Contribute to regional economic development \\
\hline mension & Reduced total transport, industrial and labor costs \\
\hline & Combine commercial activities related to freight transport \\
\hline & Enable businesses to respond to demands faster \\
\hline & Increase of transport turnover \\
\hline & Ease of operation and transportation \\
\hline Environmental & benefitsDue to the planned construction of the fields seems aesthetical. \\
\hline Sub-dimension & Provide effective and nature-friendly distribution to city centers \\
\hline & Realization of environmental and legal regulations through logistics center installation, \\
\hline & $\begin{array}{l}\text { Reduce a load of traffic on the highway and environmental pollution, by allowing the } \\
\text { transport to head from the road to the railway. }\end{array}$ \\
\hline Sectoral bene & Sub-di-Provide supportive services. \\
\hline mension & $\begin{array}{l}\text { Conduct reliable and accurate of value-added activities such as cross-docking, distribu- } \\
\text { tion-related consolidation; }\end{array}$ \\
\hline & Provide opportunities for the development of the capacity of companies, \\
\hline & Enable the flexibility of companies, \\
\hline & Create a platform for companies to increase control over their distribution channels, \\
\hline & Connect with air, land, railway and sea transportation centers, \\
\hline & Promote the use of combined transportation, \\
\hline & Improve handling activities, \\
\hline & The management can be done from a center, \\
\hline & Increased quality of logistics activities; \\
\hline & Enabling optimization of product and service flow \\
\hline Social benefits & Sub-di-Ease of work as it has feeding, shelter areas, \\
\hline mension & Ensure a quality working environment, \\
\hline & Contribute to the development of employment in the region \\
\hline & Reduce truck and heavy truck circulation, increasing rail transportation, \\
\hline & $\begin{array}{l}\text { Take into account the expectations of the workforce, it offers opportunities to meet their } \\
\text { needs, }\end{array}$ \\
\hline
\end{tabular}

\section{Method}

\section{Purpose and Importance of Research}

The main aim of the study is to develop a scale for measuring the benefits of logistical clusters. Although researches have been done on logistics clusters before, there is no study in the literature in which a comprehensive measurement tool covering the benefits of logistic clustering is used. Accordingly, the 
scale developed by considering the benefits of logistics clustering as a whole constitutes the aspect of this study that will contribute to scientific life.

\section{Sample and Data Collection}

In Turkoglu district of Kahramanmaraş, a logistics village clustering was opened On October 22, 2017, with a capacity of 1,900,000 tones and a total area of $805 \mathrm{~m}^{2}$. Therefore, in this study, data were obtained from Turkoglu logistics center in Kahramanmaraş in order to develop a scale to measure the contributions of logistics centers to companies.

A field study was conducted to collect the research data and the data were obtained by questionnaire technique. Survey scale is adapted from the work of Gurbuz, Ayaz and Kebeci (2016) entitled "Logistics Village Perceptions of Production Enterprises Managers: Karabuk Province Example"; Bay and Erol's (2016) "The Importance of Logistics Villages and Its Support with Intermodal Transportation Activities: An Application in Karaman Province" and Gedik and Turgut's (2017) "Effects of Logistics Villages in International Trade on the export process: Example of Konya Province".

At the beginning, 259 foreign trade firms are identified which are members of Kahramanmaraş Chamber of Commerce and operating in the sectors of food, paper, steel kitchen-ware, textiles, clothing, etc. Then the sample size was found (with 0.05 sample error in the trust range of $p=0.5$ and $q=0.5$ ) as 155. Then 200 were asked to fill out the questionnaire and in total 155 completed questionnaires were returned. In the questionnaire, respondents were asked to mention their opinions about each one. On the research questionnaire Likert-type scale is used, which ranged from (1) "strongly disagree" to (5) "strongly agree'.

\section{Findings}

According to the results of frequency analysis of demographic data, $72 \%$ of the participants were male, $58.3 \%$ were married, $83.6 \%$ were under the age of $40,43.8 \%$ were workers and more than half $(58.6 \%)$ were undergraduate graduates. 
Table 2. The characteristics of the participants

\begin{tabular}{|c|c|c|c|c|c|c|c|}
\hline & & $\mathrm{f}$ & $\%$ & & & $\mathrm{f}$ & $\%$ \\
\hline \multirow[t]{2}{*}{ Gender } & Female & 45 & 29 & Ages & $20-30$ & 76 & 48,7 \\
\hline & Male & 110 & 72 & & $31-40$ & 58 & 37,2 \\
\hline \multicolumn{2}{|c|}{ Marital sta-Married } & 91 & 58,3 & & $41-50$ & 22 & 14,1 \\
\hline tus & Single & 65 & 41,7 & & $51+$ & 0 & 0 \\
\hline \multirow[t]{5}{*}{$\overline{\text { Education }}$} & Primary school & 3 & 1,9 & Position & & $\mathrm{f}$ & $\%$ \\
\hline & High school & 17 & 10,9 & & Senior manager & 17 & 10,9 \\
\hline & Associate Degree & 32 & 20,5 & & Middle level manager & 44 & 28,2 \\
\hline & Bachelor degree & 89 & 57,1 & & Lower level manager & 26 & 16,7 \\
\hline & Post graduate & 15 & 9,6 & & Worker & 69 & 44,2 \\
\hline
\end{tabular}

When the characteristics of the participant enterprises were examined; it was seen $75.6 \%$ of these enterprises are joint stock companies and $62.2 \%$ are in the textile sector. $34.6 \%$ of businesses have more than 500 employees, $55.8 \%$ have an operating period of more than 20 years. In terms of logistics activities, $56.9 \%$ of companies preferred outsourcing and $45.8 \%$ of them do not have any expert logistics employees.

Table 3. The characteristics of the participant enterprises

\begin{tabular}{|c|c|c|c|c|c|c|}
\hline & & f & $\%$ & & $\mathbf{f}$ & $\%$ \\
\hline Trade & Joint Stock & 118 & 75,6 & Number of $0-10$ & 2 & 1,3 \\
\hline \multirow[t]{4}{*}{ Title } & Limited & 26 & 16,7 & Employees10-50 & 28 & 17,9 \\
\hline & General Partnership & 6 & 3,8 & $50-250$ & 31 & 19,9 \\
\hline & Limited Partnership & 3 & 1,9 & $250-500$ & 41 & 26,3 \\
\hline & Other & 3 & 1,9 & $500+$ & 54 & 34,6 \\
\hline Dura- & $<1$ & 8 & 5,2 & Logistic ac-In-Place & 15 & 9,8 \\
\hline \multicolumn{2}{|c|}{ tion of $1-5$} & 14 & 9,1 & tivity typesOutsourcing & 87 & 56,9 \\
\hline \multicolumn{2}{|c|}{ business $5-10$} & 15 & 9,7 & & & \\
\hline \multirow[t]{2}{*}{ activity } & $10-20$ & 31 & 20,1 & Both of them & 51 & 33,3 \\
\hline & $20+$ & 86 & 55,8 & & & \\
\hline \multirow[t]{6}{*}{ Sectors } & Textile & 97 & 62,2 & Number ofNever & 71 & 45,8 \\
\hline & Metal & 17 & 10,9 & Logistics $\quad 1-10$ & 39 & 25,2 \\
\hline & Chemistry & 11 & 7,1 & Employees $10-20$ & 19 & 12,3 \\
\hline & Food & 17 & 10,9 & $20-30$ & 8 & 5,2 \\
\hline & Furniture & 9 & 5,8 & $30-40$ & 2 & 1,3 \\
\hline & Other & 5 & 3,2 & $40-50$ & 4 & 2,6 \\
\hline
\end{tabular}

\section{Exploratory Factor Analysis}

Subsequently, explanatory factor analysis was performed. According to data on 20 items was formed 4 sub-dimensions as economics, social, environmental and sectoral to their neighborhood with explanatory factor analysis. For determination of the number of factors, it is utilized EUROPLATFORMS 
EEIG's European Association of Transport and Logistics Centers presentation at 2015.

The results of this analysis are seen in Table 4. In accordance with the results of the explanatory factor analysis, the Kaiser-Meyer-Olkin value was 0.848 , the results of the Bartlett test were 0.000 . This resulted in the scale being suitable for factor analyses (Child, 1990)

Table 4. KMO and Bartlett's Test Results

\begin{tabular}{lll}
\hline Kaiser-Meyer-Olkin Measure of Sampling Adequacy. &, 848 \\
Bartlett's Test of Sphericity & Approx. Chi-Square & $2,986 \mathrm{E} 3$ \\
& df & 496 \\
& Sig. &, 000 \\
\hline
\end{tabular}

After confirming the suitability of the data for factor analysis, explanatory factor analysis was performed. As known, the main purpose of factor analysis is to downsize a large number of variables into fewer numbers and grouped. In the study, factorial grouping was based on Europlatforms EEIG's European Association of Transport and Logistics Centre's presentation at 2015.

According to the explanatory factor analysis the Sectoral benefit sub-dimension has consisted of LC15, LC16, LC17, LC18, LC20; the Social benefit sub-dimension has consisted of LC9, LC12, LC14, LC19; the Environmental benefit sub-dimension has consisted of LC5, LC6, LC8, LC10, LC11, LC13 and the Economic benefit sub-dimension has consisted of LC1, LC2, LC3, LC4, LC7. The first sub-dimension is $17,600 \%$, the second sub-dimension is $17,553 \%$, the third sub-dimension is 13,020 , the fourth sub-dimension is $9,312 \%$, explaining the benefits of the logistics cluster. The scale explained $57.484 \%$ of the total variance. 
Table 5. Results of Exploratory Factor Analysis

\begin{tabular}{|c|c|c|c|c|c|}
\hline & & $\begin{array}{ll}\text { Factor } \\
\text { Load Value }\end{array}$ & $e^{\text {Total }}$ & $\begin{array}{l}\% \text { of } \\
\text { ance }\end{array}$ & -Cumul \% \\
\hline \multirow{5}{*}{$\begin{array}{l}\text { F1: Eco- } \\
\text { nomic Ben- } \\
\text { efits Sub- } \\
\text { dimension }\end{array}$} & LC1 & $\begin{array}{l}\text { Logistics villages will develop cooperation between dif- } 0,760 \\
\text { ferent provinces and districts. }\end{array}$ & \multirow{5}{*}{3,69} & \multirow{5}{*}{17,600} & \multirow{5}{*}{17,600} \\
\hline & $\mathrm{LC} 2$ & $\begin{array}{l}\text { Through the logistics cluster, local and foreign investors } 0,481 \\
\text { will come to our province and invest. }\end{array}$ & & & \\
\hline & $\mathrm{LC} 3$ & $\begin{array}{l}\text { Logistics cluster will increase the number of employ- } 0,826 \\
\text { ment }\end{array}$ & & & \\
\hline & $\mathrm{LC} 4$ & $\begin{array}{l}\text { Through the logistics cluster, for doing logistics activities } 0,721 \\
\text { enterprises could find large numbers of skilled labor } \\
\text { force }\end{array}$ & & & \\
\hline & LC7 & $\begin{array}{l}\text { The logistics sector will contribute greatly to the econ- } 0,768 \\
\text { omy of our province. }\end{array}$ & & & \\
\hline \multirow{6}{*}{$\begin{array}{l}\text { F2: Envi- } \\
\text { ronmental } \\
\text { Benefits } \\
\text { Sub-di- } \\
\text { mension }\end{array}$} & LC5 & $\begin{array}{l}\text { Through the establishment of the logistics cluster in a0,641 } \\
\text { single area, visual pollution decreases and the environ- } \\
\text { ment becomes more organized }\end{array}$ & \multirow{6}{*}{3,686} & \multirow{6}{*}{17,553} & \multirow{6}{*}{5,153} \\
\hline & LC6 & $\begin{array}{l}\text { Through the logistics cluster, carbon monoxide emis- } 0,850 \\
\text { sions will be reduced because of the mass transportation }\end{array}$ & & & \\
\hline & LC8 & $\begin{array}{l}\text { Through the logistics cluster, waste resources will be } 0,853 \\
\text { eliminated. }\end{array}$ & & & \\
\hline & LC10 & $\begin{array}{l}\text { Through building installation function The logistics } 0,772 \\
\text { cluster will reduce noise pollution }\end{array}$ & & & \\
\hline & LC11 & $\begin{array}{l}\text { Through the logistics cluster, the costs of preventing en- } 0,627 \\
\text { vironmental pollution caused by logistics activities will } \\
\text { be reduced. }\end{array}$ & & & \\
\hline & LC13 & $\begin{array}{l}\text { Through the logistics cluster, the traffic caused by sec- } 0,531 \\
\text { toral transportation will decrease, so will the transporta- } \\
\text { tion structures such as new roads, road widening and } \\
\text { intersections made unconsciously. }\end{array}$ & & & \\
\hline \multirow{4}{*}{$\begin{array}{l}\text { F3: Social } \\
\text { Benefits } \\
\text { Sub-di- } \\
\text { mension }\end{array}$} & LC9 & $\begin{array}{l}\text { With the logistics cluster, social areas such as accommo-0,675 } \\
\text { dation and restaurants will increase in our province. }\end{array}$ & \multirow{4}{*}{$-2,734$} & \multirow{4}{*}{13,020} & \multirow{4}{*}{48,173} \\
\hline & LC12 & $\begin{array}{l}\text { With the logistics cluster, Kahramanmaraş will become0,746 } \\
\text { a center of attraction in terms of industry and tourism. }\end{array}$ & & & \\
\hline & LC14 & $\begin{array}{l}\text { Cultural diversity increasing in our province as the pop-0,741 } \\
\text { ulation will increase due to logistics clusters. }\end{array}$ & & & \\
\hline & LC19 & $\begin{array}{l}\text { The logistics cluster will provide a competitive ad- } 0,523 \\
\text { vantage to the local sector. }\end{array}$ & & & \\
\hline \multirow{5}{*}{$\begin{array}{l}\text { F4: Sectoral } \\
\text { Benefits } \\
\text { Sub-di- } \\
\text { mension }\end{array}$} & $1 \mathrm{LC} 15$ & $\begin{array}{l}\text { Logistics cluster will create new business areas from a0,671 } \\
\text { sectoral point of view }\end{array}$ & \multirow{5}{*}{$-1,955$} & \multirow{5}{*}{9,312} & \multirow{5}{*}{57,484} \\
\hline & LC16 & $\begin{array}{l}\text { Access to competing markets will be easier through lo- } 0,774 \\
\text { gistics clusters }\end{array}$ & & & \\
\hline & LC17 & $\begin{array}{l}\text { Through the logistics cluster, a strong transportation } 0,878 \\
\text { network will be formed between the production points }\end{array}$ & & & \\
\hline & LC18 & Logistics clusters will develop in-sector cooperation $\quad 0,836$ & & & \\
\hline & LC20 & Logistics clusters will increase customer satisfaction. & & & \\
\hline
\end{tabular}

To examine the consistency of the whole scale and each sub-factors Cronbach's alpha reliability coefficient was used. On examination Table 6; the results for the whole scale reliability coefficient was found as 0.884 (for 20 
items); for the economic benefits sub-scale was found as 0,502 (for 5 items); for the environmental benefits sub-scale consisting was found as 0.885 (for 6 items); for the social benefits sub-scale was found as 0.779 (for 4 items); and for the sectoral benefits sub-scale was found as 0.887 (for 5 items).

Table 6. Reliability Coefficients Relating to Logistics Clusters Benefits Basic Scale

\begin{tabular}{lll}
\hline Sub-dimension & Number of Items & Cronbach's Alpha \\
\hline Logistic Cluster Benefits & 20 & 0,894 \\
Economic Benefits & 5 & 0,502 \\
Environmental Benefits & 6 & 0,885 \\
Social Benefits & 4 & 0,779 \\
Sectoral Benefits & 5 & 0,887 \\
\hline
\end{tabular}

\section{Confirmatory Factor Analysis}

Confirmatory Factor Analysis (CFA): CFA is a generally used analysis method for the development of measurement models and provides significant conveniences. This method is a process for creating a variable (factor) based on variables observed through a pre-created model. It is usually used in scale development and validity analyses or intends to valid a predetermined structure (Yaşlığlu, 2017, p.78).

The following the confirmatory factor analysis basic model has been drawn in line with the descriptive factor analysis, which includes the benefits of logistics clusters, its relevant sub-dimensions and related substances (Figure 1.) 


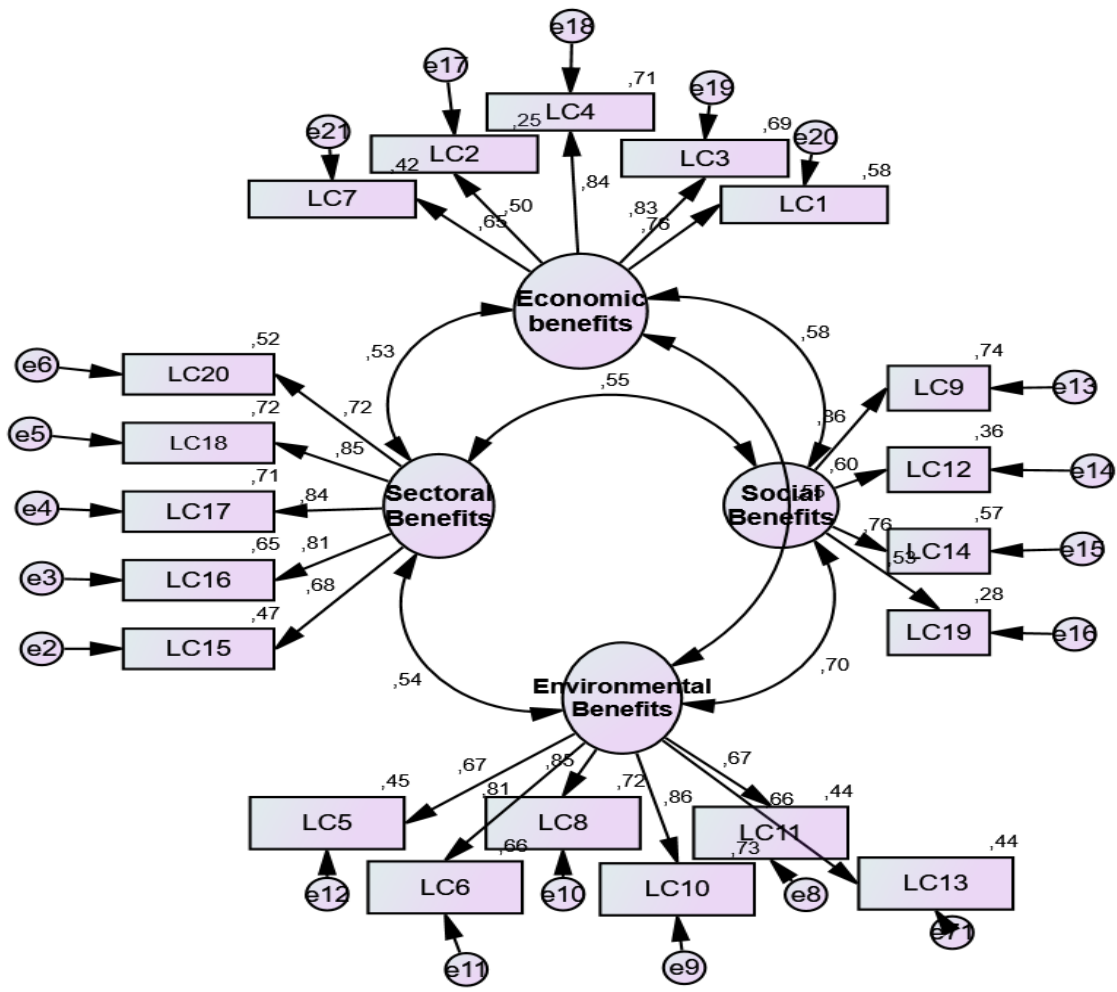

chi squared $=364,759 \mathrm{df}=164 \mathrm{p}=, 000$ Standardized estimates

Figure 1. The Basic Model and Values of it

After the model was tested, there is found that $\mathrm{X} 2 / \mathrm{df}=364.759 / 164=2,224$; $\mathrm{GFI}=0.817 ; \mathrm{IFI}=0.887 ; \mathrm{CFI}=0,885 ; \mathrm{AGFI}=0.766 ; \mathrm{RMSEA}=0.077$.

Table 7. Confirmatory Factor Analysis Fit Indices (Türkmen, 2012, p. 51)

\begin{tabular}{llll}
\hline Indices & Value & Judgment criteria & Result \\
\hline X2/df & $364,759 / 164=2,224$ & $3 \geq x \geq 2$ & Acceptable fit \\
NFI & 0,812 & $>0,90$ & Bad Model fit \\
NNFI & 0,867 & $>0,95$ & Bad Model fit \\
CFI & 0,885 & $>0,95$ & Bad Model fit \\
IFI & 0,887 & $>0,90$ & Bad Model fit \\
AGFI & 0,766 & $>0,85$ & Bad Model fit \\
GFI & 0,817 & $>0,90$ & Bad Model fit \\
RMSEA & 0,087 & $0,08 \geq R M S E A>0,05$ & Bad Model fit \\
SRMR & 0,0693 & $0,1 \geq S R M R \geq 0,05$ & Acceptable fit
\end{tabular}


After the first confirmatory factor analysis was done, some modifications were performed. 5 questions that decrease the value were removed from the model (LC20 from sectoral benefit sub-dimension, LC19 from social benefit sub-dimension, LC13 from environmental benefit sub-dimension and LC2, LC7 from the economic benefit sub-dimension) and added covariance to some latent variables. After analysis, it is seen that the modified model is well fit to the data.

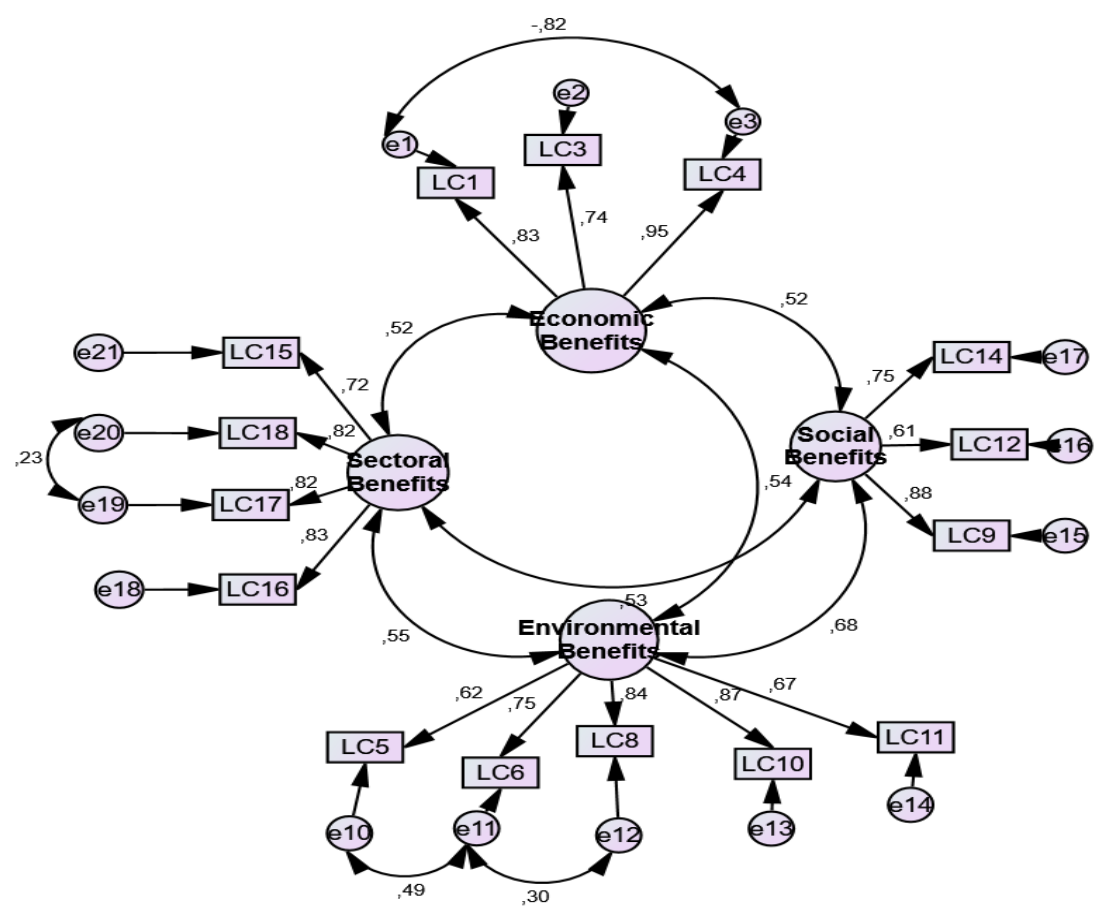

chi squared $=137,579 \mathrm{df}=80 \mathrm{p}=, 000$ Standardized estimates

Figure 2. The Modified Model and Values of it

Table 8 shows that $X 2 / \mathrm{df}=1,691 ; \mathrm{GFI}=0.903 ; \mathrm{IFI}=0.961 ; \mathrm{CFI}=0.960$; $\mathrm{AGFI}=$ 0.850; RMSEA $=0.077$. According to results the model is adapted to the data. These results mean the validity of the 4 -factor structure revealed by explanatory factor analysis has been confirmed by the confirmatory factor analysis. So the designed scale can be used to measure the benefits of logistics clusters. 
Table 8. Confirmatory Factor Analysis Fit Indices (Türkmen, 2012,p.51)

\begin{tabular}{llll}
\hline Indices & Value & Judgment criteria & Result \\
\hline X2/df & $137,579 / 80=1,720$ & $2 \geq \times \geq 0$ & Good fit \\
NFI & 0,905 & $0,95 \geq N F I \geq 0,90$ & Acceptable fit \\
NNFI & 0,944 & $0,97 \geq \mathrm{NNFI} \geq 0,95$ & Good fit \\
CFI & 0,957 & $>0,95$ & Acceptable fit \\
IFI & 0,958 & $>0,95$ & Good fit \\
AGFI & 0,850 & $0,90>$ AGFI $\geq 0,85$ & Acceptable fit \\
GFI & 0,901 & $>0,90$ & Acceptable fit \\
RMSEA & 0,064 & $0,80 \geq$ RMSEA $>0,05$ & Acceptable fit \\
SRMR & 0,052 & $0,1 \geq S R M R \geq 0,05$ & Acceptable fit \\
\hline
\end{tabular}

On examination of Table 9, as a result of reliability analyses of Logistics clusters Benefits Modified Scale, Cronbach Alpha value is seen to be calculated as 0.910 as the whole scale (consisting of 15 items); 0,852 as the economic benefits sub-dimension (consisting of 3 items); 0,876 as the environmental benefits sub-scale (consisting of 5 items); 0.789 as the social benefits sub-scale (consisting of 3 items); and 0.876 for the sectoral benefits sub-scale (consisting of 4 items).

Table 9. Reliability Coefficients Relating to Logistics Clusters Benefits Modified Scale

\begin{tabular}{lll}
\hline Scales & Number of Items & Cronbach's Alpha \\
\hline Logistic Cluster Benefits & 15 & 0,910 \\
Economic Benefits & 3 & 0,852 \\
Environmental Benefits & 5 & 0,876 \\
Social Benefits & 3 & 0,789 \\
Sectoral Benefits & 4 & 0,876 \\
\hline
\end{tabular}

Another important expectation for the confirmatory factor analyses is, coefficients of the regression are high and significant. Standardized regression weight coefficients are shown in table 10. Regression values show the power of the observed variables to predict hidden variables, that is, factor loads. At this model coefficients of the regression are well enough high. 
Table 10. Standardized Regression Weights

\begin{tabular}{llll}
\hline & & & Estimate \\
\hline LC4 & $<--$ & Economic Benefits &, 879 \\
LC3 & $<--$ & Economic Benefits &, 797 \\
LC1 & $<--$ & Economic Benefits &, 754 \\
LC10 & $<--$ & Environmental Benefits &, 837 \\
LC8 & $<--$ & Environmental Benefits &, 771 \\
LC6 & $<--$ & Environmental Benefits &, 746 \\
LC5 & $<--$ & Environmental Benefit's &, 698 \\
LC11 & $<--$ & Environmental Benefits &, 687 \\
LC18 & $<--$ & Sectoral Benefits &, 853 \\
LC17 & $<--$ & Sectoral Benefits &, 852 \\
LC16 & $<--$ & Sectoral Benefits &, 803 \\
LC9 & $<--$ & Social Benefits &, 860 \\
LC14 & $<--$ & Social Benefits &, 743 \\
LC12 & $<--$ & Social Benefits &, 597 \\
\hline
\end{tabular}

The results of the inter-dimensional correlation were analyzed as a result of the explanatory and confirmatory factor results showing that the model was significant. Inter-dimensional correlation values, standard deviation and averages are given in Table 11. As seen that all correlations make sense at error level 0.01. According to the results obtained, the sub-dimensions are related to each other and, as expected, these correlations are moderate.

Table 11. Means of Sub-dimensions, Standard Deviations and Correlations Analyze

\begin{tabular}{lccllll}
\hline Sub-dimensions & Mean & S.D. & Economic B. & Social B. & Sectoral B. & $\begin{array}{l}\text { Environmental } \\
\text { B. }\end{array}$ \\
\hline 1.Economic Benefits & 4,028 & 0,79 & 1 & & & \\
2. Social Benefits & 3,610 & 0,75 & $0,459^{* *}$ & 1 & & \\
3.Sectoral Benefits & 3,919 & 0,82 & $0,481^{* *}$ & $0,488^{* *}$ & 1 & 1 \\
4.Environmental & 3,717 & 0,75 & $0,498^{* *}$ & $0,596^{* *}$ & $0,484^{* *}$ & 1 \\
Benefits & & & & & & \\
\hline
\end{tabular}

${ }^{* *}$ Correlations at error level 0.01 are significant (2-tailed)

\section{Conclusion}

Cluster style structures, known for many years, greatly benefit the economies, social lives, sectoral activities, and environmental sensitivities of the countries, regions, cities, etc. that are increasingly widespread in today's complex, knowledge-based and dynamic global world. In line with this importance, it is seen that there are many studies on this subject in the literature.

In this study, to contribute to the literature a scale was developed to determine and measure the benefits of logistic clusters. While developing the scale, 
it was utilized from Gurbuz, Ayaz, and Kebeci's (2016), Bay and Erol's (2016), and Gedik and Turgut's (2017) studies about logistics clusters. And this scale with 20 items survey was applied to 156 enterprises operating foreign trade in Kahramanmaraş.

First of all, explanatory factor analysis was done to the data obtained. For determination of the number of factors, is utilized Europlatforms EEIG's European Association of Transport and Logistics Centre's presentation (2015). In accordance with the first exploratory factor analysis, the scale has explained $57.484 \%$ of the total variance, and the whole scale's reliability coefficient was detected as 0.894 .

Then, the scale was confirmed by the confirmatory factor analysis. According to the resulting model fit values, it was determined that the model did not fit with the data. Therefore, 5 questions were removed from the model and modification was made by adding covariance to some latent variables. After analysis, it is seen that the modified model is well fit to the data and the results of the reliability coefficient of the entire scale were 0.910 . The scale developed is suitable for use with the number of substances and the statistical values it has. In this sense, it is thought that it will make an important contribution to the literature

As with all studies, this study has got also some limitations. One of them is there was the number of participants, another one is the collection of data only from Kahramanmaras local businesses and the last one is the scale has not tested on all types of logistics clusters. All these make limitation the generalizability of the findings. Therefore, in future studies, this model should be better to reapply to many numbers of participants, various sectors, different types of clusters in different regions.

\section{References}

Aydın, G. T. and Öğ̈̈t, K. S. (2008a). Lojistik köy nedir? Paper presented at the 2. Uluslararası Demiryolu Sempozyumu İstanbul.

Bakan, İ. and Şekkeli, Z. H. (2017). Lojistik yönetimi. İstanbul: BETA yayınevi.

Baki, R. (2016). Avrupa birliği ülkeleri ile Türkiye'deki lojistik köy uygulamaları ve uygun kuruluş yeri seçimi. Adnan Menderes Üniversitesi Sosyal Bilimler Enstitüsü Dergisi, 5, 148-162. 
Bay, M. and Erol, F. (2016). Lojistik köylerin önemi ve intermodal taşımacilık faaliyetleriyle desteklenmesi: Karaman ilinde bir uygulama. KMÜ Sosyal ve Ekonomik Araştırmalar Dergisi, 18(30), 124-134.

Baydar, A. M., Sural, H. and Çelik, M. (2019). Potential effects of logistics clusters: The case of Turkish Freight Villages. Journal of Cleaner Production, 233(1), 399-411. https://doi.org/10.1016/j.jclepro.2019.05.294.

Bezirci, M. and Dündar O. A. (2011). Lojistik köylerin işletmelere sağladığı maliyet avantajları. Trakya Üniversitesi Sosyal Bilimler Dergisi, 13, 292-307.

Child, D. (1990). The essentials of factor analysis: Cassell Educational (2nd ed). London ; New York : Holt, Rinehart and Winston.

Chung, T. W. (2016). A study on logistics cluster competitiveness among Asia main countries using the Porter's diamond model. The Asian Journal of Shipping and Logistics, 32(4), 257-264.

De Langen, P. (2002). Clustering and performance: the case of maritime clustering in the Netherlands. Maritime Policy and Management, 29(3), 209-221.

Delgado, M., Porter, M. E. and Stern, S. (2016). Defining clusters of related industries. Journal of Economic Geography, 16(1), 1-38.

Dmuchowski, R. (2019). The concept of logistics clusters and efficiency of economic enterprises. Journal of European Economy, 18(3), 351-361.

Elgün, N. M. (2011). Ulusal ve uluslararası taşıma ve ticarette lojistik köylerin yapılanma esasları ve uygun kuruluş yeri seçimi. Afyon Kocatepe Üniversitesi İ.̇.B.F. Dergisi, 13, 203-226.

Eraslan, H., Bulu, M. and Bakan, İ. (2008). Kümelenmeler ve inovasyona etkisi: Türk turizm sektöründe uygulamalar. Seyahat ve Otel Işletmeciliği Dergisi, 5(3), 1529.

Eraslan, İ. H. and Dönmez, C. Ç. (2017). Endüstriyel kümelenme uygulamalarının Türkiye genelinde incelenmesi: Sanayi, tarım ve hizmet sektörleri açısından bir değerlendirme. Elektronik Sosyal Bilimler Dergisi, 16(61), 325-368.

Europlatforms (2015). Corporate Presentation. The European logistics platforms association, wwww.europlatforms.eu/wp-content/uploads/2016/01/Corporate-Presentation-2015-Europlatforms-Final 20151229.pdf.

Facility for Investment Climate Advisory Services - FIAS. (2008). Special economic zones. performance, lessons learned, and implications for zone development, the World Bank Group: https://documents1.worldbank.org/curated/en/343901468330977533/pdf/458690WP0Box331s0April200801PUBLIC1.pdf. 
Gedik, H. and Turgut, M. (2017). Uluslararası ticarette lojistik köylerin ihracat sürecine etkileri: Konya ili örneği. Uluslararası Bilimsel Araştırmalar Dergisi, 2(7), 129-147.

Gürbüz, A., Ayaz, N. and Kebeci, S. (2016). Üretim işletmeleri yöneticilerinin lojistik köy algıları: Karabük ili örneği. Karabük Üniversitesi Sosyal Bilimler Enstitüsü Dergisi, 2(Özel Sayı) , 1-19.

Kasarda, J. D. (2008). The evolution of airport cities and the aerotropolis. Dalam JD Kasarda, Airport Cities, The Evolution. London: Insight Media.

Kayıkçı, Y. (2010). A conceptual model for intermodal freight logistics centre location decisions, procedia social and behavioral sciences. The Sixth International Conference On City Logistics, 6297-6311.

Lindholm, M. and Behrends, S. (2012). Challenges in urban freight transport planning-a review in the Baltic Sea Region. Journal of Transport Geography, 22, 129136.

Miller, T., Friesz, T. ve Tobin, R.(1996). Equilibrium facility location on networks. Springer Science \& Business Media. ISBN 978-3-642-08227-6

Olsson, J. and Woxenius, J. (2012). Location of freight consolidation centres serving the city and its surroundings. Procedia-Social and Behavioral Sciences, 39, 293306.

Rivera, L., Gligor, D. and Sheffi, Y. (2016). The benefits of logistics clustering, International Journal of Physical Distribution \& Logistics Management, 46(3), 242-268. https://doi.org/10.1108/1]PDLM-10-2014-0243

Sun, H., Gao, Z. ve Wu, J. (2008). A Bi-Level Programming model and solution algorithm for the location of logistics distribution centers. Applied mathematical modelling, 32(4), 610-616. https://doi.org/10.1016/j.apm.2007.02.007.

TCDD. (2017). Faaliyet Raporu. T.C. Devlet Demiryollari İşletmesi Genel Müdürlüğü, Strateji Geliştirme Dairesi Başkanliği, Stratejik Planlama Şubesi Müdürlüğü. TCDD Taşimacilik AŞ, Yayın No: 2018-1.

Tek, Ö.B. and Mucan, B. (2010). Tedarik zinciri ve lojistik'in verimliliğini arttıran bir proje: Lojistik köyler. 9. Ulusal İşletmecilik Kongresi, 6-8 Mayıs, Zonguldak, p.327-332.

Tsamboulas, D. ve Dimitropoulos,I.. (1999). Appraisal of investments in european nodal centres for goods - Freight villages: A comparative analysis, Transportation, 26, 391-398.

Tsamboulas, D. ve Kapros, S. (2003). Freight village evaluation under uncertainty with public and private financing. Transport Policy, 10(2), 141-156. 
Türkmen, M. (2012). Öznel iyi oluşun yapısı ve anababa tutumları, özsaygı ve sosyal destekle ilişkisi: Bir model sinaması. Uşak Üniversitesi Sosyal Bilimler Dergisi, 5(1), 41-73.

Yang, H., L. Yang, L, S.H. and Yang, S. H. (2010). Hybrid zigbee rfid sensor network for humanitarian logistics centre management, Journal of Network and Computer Applications, 34(3), 938-948.

Yaşlığlu, M. M. (2017). Sosyal bilimlerde faktör analizi ve geçerlilik: Keşfedici ve doğrulayıc faktör analizlerinin kullanılması. İstanbul Üniversitesi İşletme Fakültesi Dergisi, 46(Özel say1), 74-85.

Ylldırım, K. and Demet, E. (2016). Rekabet ve değer zinciri çerçevesinde lojistik kümelenme örnekleri olarak singapur lojistik kümelenmesi ve Ankara Lojistik Üssü. Trakya Üniversitesi Sosyal Bilimler Dergisi, 18(2), pp. 395-420.

Zaralı, F., Yazgan, H. R. and Delice, Y. (2019). AHP ve VIKOR bütünleşik yaklaşımıla lojistik merkez yer seçimi: Kayseri ili örneği. Erciyes Üniversitesi Fen Bilimleri Enstitüsü Fen Bilimleri Dergisi, 34(3), 1-9.

\section{Citation Information}

Şekkeli, Z. H. and Bakan, İ. (2021). Regional benefits of logistic clusters: A study of scale development. OPUS-International Journal of Society Studies, 18(43), 6143-6161. DOI: 10.26466/opus.873593. 